\title{
Construction of Allometric Relationships to Predict Growth Parameters, Stem Biomass and Carbon of Eucalyptus grandis Growing in Sri Lanka
}

\author{
S.M.C.U.P. Subasinghe* \\ Department of Forestry and Environmental Science, University of Sri Jayewardenepura, Sri Lanka
}

Date Received: 04-06-2015 Date Accepted: 26-10-2015

\begin{abstract}
Enhancement of carbon storage through the establishment of man-made forests has been considered as a mitigation option to reduce increasing atmospheric $\mathrm{CO}_{2}$ levels. Therefore the present study was carried out to estimate the biomass and carbon storages of the main stem of Eucalyptus grandis using allometric relationships using the plantations of Nuwara Eliya and Badulla districts in Sri Lanka. Tree diameter and total height were measured for the samples trees and stem volume was estimated using a previously built individual model for the same species. Stem biomass was estimated using core samples and carbon was determined using Walkley-Black method. Finally the biomass values were converted separately to the carbon values. Non-liner regression analysis was employed for the construction of models which had age as the explanatory variable. Linear regression was used in order to build the models to predict the above ground and stem biomass and carbon using volume as the explanatory variable. For both linear and non-linear types, the model quality was tested using $\mathrm{R}^{2}$ and fitted line plots. According to the results, stem biomass and carbon values at the $7^{\text {th }}$ year were $110.8 \mathrm{~kg}$ and $68.7 \mathrm{~kg}$ respectively. Stem biomass and carbon values at the $40^{\text {th }}$ year were $1,095.8 \mathrm{~kg}$ and 679.4 $\mathrm{kg}$ respectively. Carbon content at the age 20 was $62.0 \%$ from the stem biomass. Exponential models were proven to be better than the logistic models to predict the diameter, height, stem volume, biomass and carbon with age. $\mathrm{R}^{2}$ values and the fitted line plots indicated that the selected models are of high quality. Linear models built to predict the stem biomass and carbon using stem volume also showed the high accuracy of these models which had $\mathrm{R}^{2}$ values above $97.9 \%$.
\end{abstract}

Key words: Eucalyptus grandis, forest biomass, forest carbon, allometric equations

\section{Introduction}

Eucalyptus grandis Hill ex Maiden also known as flooded gum belongs to the family Myrtaceae and is native to the east coast of Australia (Geary et al., 1983). It is a tall, straight tree which can grow up to $50-55 \mathrm{~m}$ in height and $180 \mathrm{~cm}$ in diameter and has a widespread thin crown at maturity (FAO, 1981). The grey colour bark is thin and deciduous, shedding in strips to expose a smooth surface marked with flowing patterns of silvery white, gray or light green. It is one of the most important commercial eucalypt species and it has been successfully used for pulpwood and fuel; and its wood has potential for poles, pallets, veneer, and other products (Geary et al., 1983). According to the Sri Lanka Forestry Sector Master Plan (FSMP 1995), E. grandis was first introduced in late 1800s as a fuel wood

*Correspondence: upuls@sjp.ac.lk

Tel: +94714450339

ISSN 2235-9370 Print/ISSN 2235-9362 Online @ University of Sri Jayewardenepura 
for the drying ovens of tea factories and established in large scale in the up country. After 1953, Forest Department established E. grandis and E. microcorys plantations in the up country of Sri Lanka, especially in degraded lands for the rehabilitation. However, after realising the value of timber, those plantations are currently mainly maintained as even-aged monocultures to obtain sawn timber, transmission poles and railway sleepers.

Total extent of E. grandis plantations managed by the Forest Department in Sri Lanka is approximately 4,000 ha (Bandaratillake, 2000). All tea estates located in the upcountry also maintain large areas of Eucalyptus plantations for both timber and fuelwood. If these privately owned plantations are added to the government plantations, Sri Lanka has a large extent (most probably double the recorded figure) of flooded gum plantations. Unfortunately the information on the privately owned plantations is not readily available.

Global climate change has inspired an increasing interest of scientific and political communities in the study of global carbon storage and of the carbon balance (Landsberg et al., 1995). The estimation of biomass is an essential aspect of studies of carbon storage and carbon balance. Although weighing the actual tree biomass in the field is undoubtedly the most accurate method to determine tree biomass, it is an extremely time consuming and destructive method, that is generally restricted to small areas and small tree sample sizes (Ketterings et al., 2001).

Use of allometric relationships yields a non-destructive and indirect measurement of biomass compartments, and is often the preferred approach since it is less time consuming and less expensive than direct measurements (St. Clair, 1993). These techniques, involve relationships between tree biomass and tree stem diameter and/or height (Spelcht and West, 2006). In 1994, Niklas said that allometry, relating easily measured variable to other structural and functional characteristics, is the most common and reliable method for estimating biomass, net primary production, and biogeochemical budgets in forest ecosystems (Gower et al., 1994; Wang, 2006). Substantial research programs are usually undertaken to develop such allometric relationships for application with particular tree species in particular forest ecosystems (Spelcht and West, 2006).

Forests play an important role in global carbon budget as carbon sinks and throughout emission of $\mathrm{CO}_{2}$ (Sedjo 1990; Dixon et al., 1994, Gamage et al., 2010). Forests hold two third of terrestrial carbon and as the forest biomass increase over the time, the stock of sequestered carbon stock in the standing forest and soils will also increase. Usually young forests may have a relatively modest carbon stock due to its low biomass, but at the same time generate substantial flows into that stock due to the rapid growth of juvenile trees (Roger et al., 1997). Brown et al., (1996) estimated that deforestation contributes about 1.8 giga-tonne of carbon per year. However, as forests remove $\mathrm{CO}_{2}$ from the atmosphere through photosynthesis, it has been estimated that, the reduction is between 1.1 to 8.0 gigatonne per year. Managed forests can function as net sinks for atmospheric $\mathrm{CO}_{2}$, despite the period of $\mathrm{CO}_{2}$ release at harvesting. In fact, sustainably managed forests are needed to maintain the sequestration capacity of forest ecosystem, i.e., the use of stem wood in forest industry makes it possible to remove carbon into storage outside the forest ecosystem (Marland and Marland, 1992).

Apart from aboveground vegetation, belowground tree root biomass, forest floor, and mineral soil provide large C pools (Johnson et al., 2003; Oliver et al., 2004). However, there has been some disagreement in literature about whether or not an increase in soil carbon may be achieved through forest plantations. Furthermore, due to the immense effort required in obtaining a precise estimate of 
tree root biomass, carbon storage in tree roots is often neglected or estimated from standard root to shoot ratios (Kurz et al., 1996; Cairns et al., 1997). Estimations of growth and yield are important across the full planning spectrum of forest stands from the strategic level through to the operational level (Louw and Scholes, 2006). The ability to understand and predict forest growth underpins sustainable silvicultural management. Accurate predictions of growth and yield of forest plantations remain also important to the forest industry (Louw, 1999; Dye, 2001). In any modelling project, several aspects of the posed problem need to be reconciled: conceptual, mathematical, engineering and ecological aspects. Growth equations have a quite different character from transparent equations; they are heuristic generalisations rather than applications of an underlying theory (Hauhs et al., 2003).

\section{Methodology}

\subsection{Site selection}

In order to cover a wide geographical range in data collection, even-aged E. grandis monoculture plantations listed in Table 1 were selected from Nuwara-Eliya and Badulla Forest Divisions for the present study.

Table 1: Plantations selected from Badulla and Nuwara Eliya Forest Divisions for the current study.

\begin{tabular}{llc}
\hline Division & Plantation & Planted year \\
\hline Badulla & Haliela & 1972 \\
& Passara & 1987 \\
Bandarawela & 1980 \\
& Haputale & 1972 \\
Gurutalawa & 1972 \\
& Ohiya & 1970 \\
& Bambrarakele & 1979 \\
& Bambrarakele I & 1975 \\
Bambrarakele II & 1975 \\
Bambrarakele & 1971 \\
Bambrarakele & 1967 \\
Dixons Corner & 1978 \\
Mahakudugala & 1977 \\
Kandapola & 2000 \\
Kandapola & 1995 \\
Kandapola & 1991 \\
Kandapola & 1982 \\
Kandapola & 1987 \\
Norton Bridge & 1971 \\
Pattipola & 2000 \\
Pattipola & 1991 \\
Pattipola & 1987 \\
Pattipola & 1972 \\
Pattipola & 1967 \\
Piduruthalagala & 1967 \\
Pundalu Oya & 1987 \\
Pundalu Oya & 1983 \\
Ramboda & 1979 \\
Rilagala & 1974 \\
Sandathenna & 1975 \\
\hline &
\end{tabular}




\subsection{Sampling and data collection}

Randomly demarcated 0.02 ha circular sample plots were used for the data collection. The number of samples needed at $95 \%$ probability level was determined by using the equation 1 after a preliminary sampling procedure. The numbers of samples vary for each plantation from 5 to 10 (Philip, 1994).

$$
n=\frac{4 \times(c v \%)^{2}}{(A E \%)^{2}}
$$

where:

$4=$ approximation of the $t$ value at $95 \%$ probability

$C V=$ coefficient of variation among the selected plots

$n$ = number of sample plots required

\subsection{Measurements taken}

E. grandis plantations selected for the present study was even-aged monocultures and age of the selected plantations were obtained by the FORDATA database maintained by the Sri Lanka Forest Department. Diameter at breast height $(\mathrm{dbh})$, i.e., the diameter of the tree stem at the point of $1.3 \mathrm{~m}$ above the ground from the uphill side was measured using a diameter tape. Total tree height which is the height from the bottom of the tree to its highest growing point was measured using a Blume-Leiss altimeter.

\subsection{Calculation of stem volume}

The stem volume of $E$. grandis trees were calculated using the model given in equation 2 developed by Subasinghe (2001) for the same species.

$$
v=0.3648(g \times h)
$$

where:

$$
\begin{aligned}
& g=\text { tree basal area (calculated from tree diameter), } \mathrm{m}^{2} \\
& h=\text { total height }, \mathrm{m} \\
& v=\text { stem volume, } \mathrm{m}^{3}
\end{aligned}
$$

\subsection{Estimation of stem biomass and carbon}

Early studies conducted on forest trees indicated that the biomass per unit volume (wood density) does not become significantly different along the stem from the bottom to the top (Samarasekara, 2013; Subasinghe and Haripriya, 2014). Therefore, it was decided to use only one core sample from the tree stem for the analysis of carbon and biomass. Those core samples were extracted at the breast height and green volume and oven dry weight were measured. Then those were oven-dried at $105{ }^{0} \mathrm{C}$ until a constant weight was achieved. The dry weight of the entire main stem was then calculated using equation 3 .

$$
w_{s}=\frac{w_{c} \times v}{v_{c}}
$$

where:

$$
\begin{aligned}
& v_{c}=\text { green volume of the core sample }, \mathrm{m}^{3} \\
& w_{c}=\text { dry weight of the core sample, } \mathrm{kg} \\
& w_{s}=\text { total dry mass of the stem, } \mathrm{kg}
\end{aligned}
$$


The available carbon was determined by using the Walkley and Black method for the dried samples and it was converted to the entire stem using equation 4.

$$
c_{s}=\frac{c_{c}}{v_{c}} \times v
$$

where:

$$
\begin{aligned}
& c_{c}=\mathrm{C} \text { amount of the core sample, } \mathrm{kg} \\
& c_{s}=\mathrm{C} \text { amount of the stem, } \mathrm{kg}
\end{aligned}
$$

\subsection{Development of relationships}

Diameter and height growth of the trees show increasing relationships with age and therefore allometric relationships between growth parameters and the age were determined using the methods described in the following sections.

In order to build the allometric models to identify the variation of dbh, total height and stem volume with the age, the relationships shown in the equations 5, 6 and 7 were used.

$$
\begin{aligned}
& \text { dbh }=f(\text { age }) \\
& \text { height }=f(\text { age }) \\
& \text { stem volume }=f(\text { age })
\end{aligned}
$$

According to the biological growth patterns, linear relationships of the selected variables with age could not be accepted. Therefore non-linear regression analyses were used to quantify the above mentioned relationships using GENSTAT software. Stem biomass and stem carbon should exhibit a strong relationship with the stem volume and therefore the following relationships were also built using linear regression analysis using GENSTAT software.

$$
\begin{aligned}
& \text { stem biomass }=f(\text { stem volume }) \\
& \text { stem carbon }=f(\text { stem volume })
\end{aligned}
$$

Linear models were fitted to the theoretically established relationships where volume was the explanatory variable. All those models were developed without intercepts in this study because when the explanatory variable is zero, the respective response variables should not exist. Both exponential and logistic curves were fitted to the data for the relationships (equations 5 to 7 ) had age as the explanatory variable.

\subsection{Evaluation of the models}

In order to identify the quality of the models, it was decided to use both quantitative and qualitative indicators. Coefficient of determination $\left(\mathrm{R}^{2}\right)$ was used as the quantitative indicator and fitted line plots were used as qualitative indicators because all relationships had one explanatory variable.

\section{Results}

The summary of the measured variables from the selected plantations is given in Table 2 and Figure 1. According to the data of Table 2 and Figure 1, plantations of age 20 and 24 indicated unusually higher growth rates than the rest of the plantations. This could be due to the impact of site qualities on the growth of E. grandis trees growing in those plantations. 
Table 2: Summary of the measured and estimated variables from the selected plantations.

\begin{tabular}{cccccc}
\hline Age, $y r$ & dbh, cm & Height, $\mathrm{m}$ & $\begin{array}{c}\text { Stem } \\
\text { volume, } \mathrm{m}^{3}\end{array}$ & $\begin{array}{c}\text { Stem } \\
\text { biomass, kg }\end{array}$ & $\begin{array}{c}\text { Stem } \\
\text { carbon, } \mathrm{kg}\end{array}$ \\
\hline 7 & 20.3 & 22.3 & 0.263 & 110.8 & 68.7 \\
12 & 21.7 & 24.1 & 0.325 & 125.8 & 72.5 \\
16 & 25.6 & 25.6 & 0.481 & 191.8 & 138.5 \\
20 & 37.6 & 34.8 & 1.410 & 463.5 & 287.4 \\
24 & 28.3 & 28.0 & 0.643 & 248.4 & 163.8 \\
28 & 49.2 & 36.3 & 2.518 & 851.4 & 520.7 \\
32 & 45.9 & 35.1 & 2.119 & 732.3 & 479.0 \\
36 & 44.1 & 38.1 & 2.123 & 695.7 & 468.0 \\
40 & 55.9 & 42.8 & 3.563 & 1095.8 & 679.4 \\
\hline
\end{tabular}

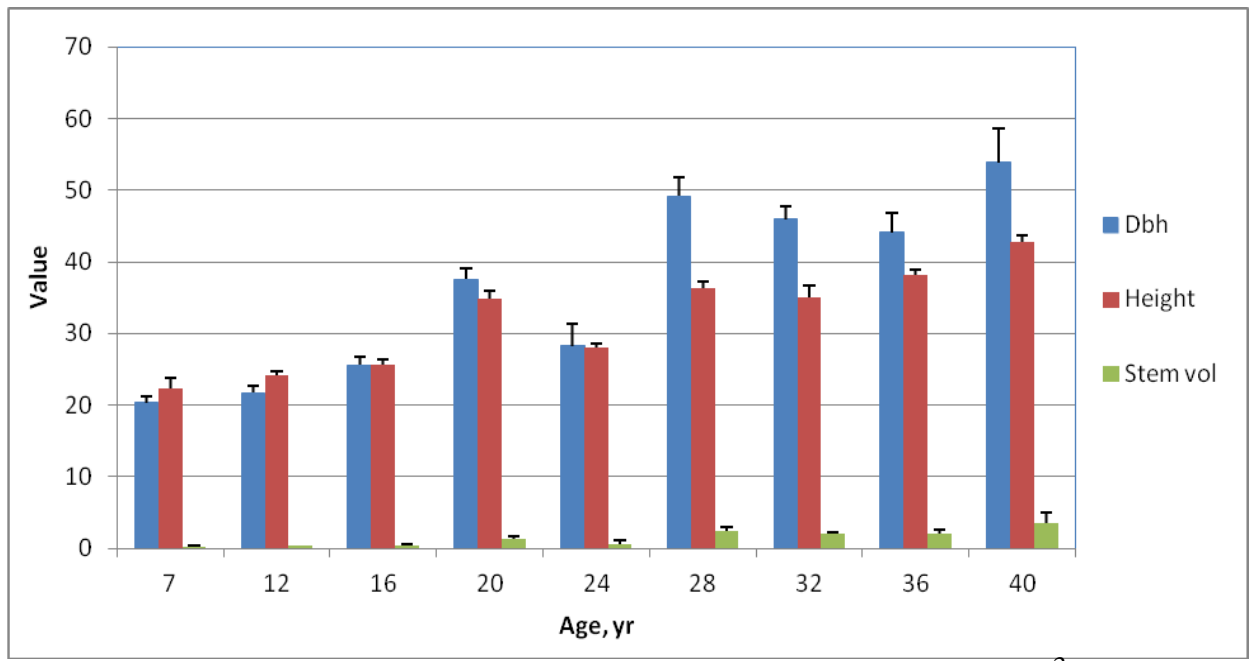

Figure 1: Variation of average $\mathrm{dbh}(\mathrm{cm})$, height $(\mathrm{m})$ and volume $\left(\mathrm{m}^{3}\right)$ values with $( \pm \mathrm{SE})$.

\subsection{Carbon and biomass variation with the age}

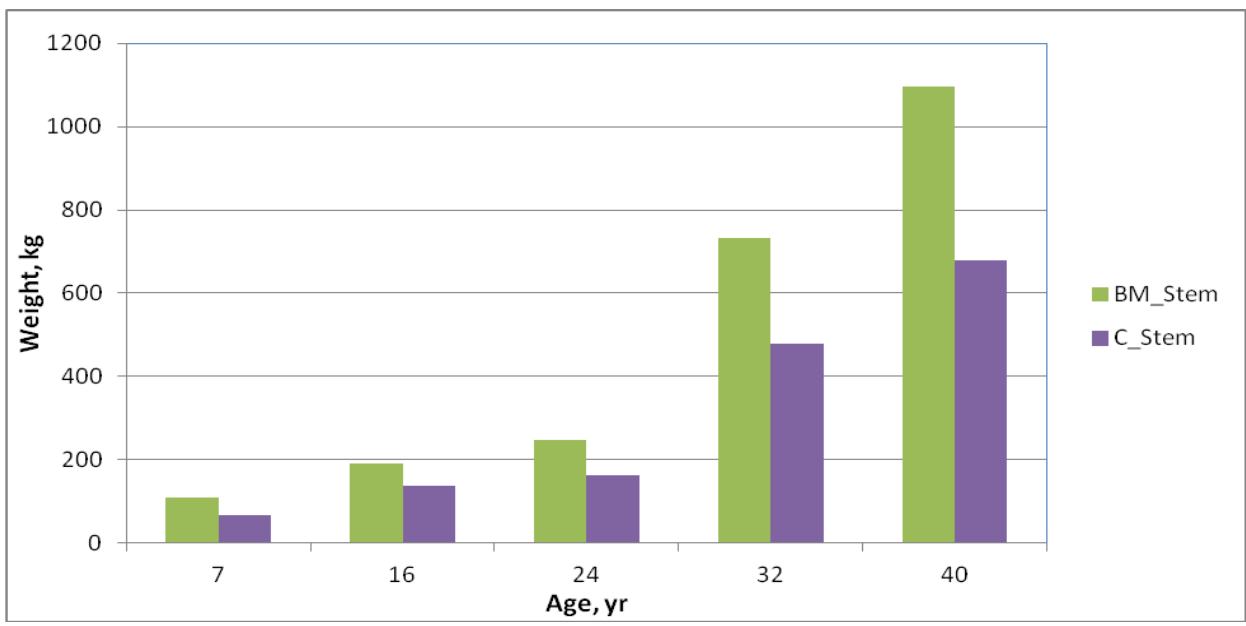

Figure 2: Variation of stem biomass and carbon values with the age. 
Figure 2 illustrates the variation of the average carbon and biomass values for each tree. According to that graph, the stem biomass of the average tree varies from $110.8 \mathrm{~kg}$ at the age 7 to $1,095.8$ at the age 40 . This indicates an average biomass increment of $29.8 \mathrm{~kg}$ per tree per annum.

Stem carbon varies from $68.7 \mathrm{~kg}$ at the age 7 to $679.4 \mathrm{~kg}$ at the age 40 (Figure 2) showing an annual carbon storage of $18.5 \mathrm{~kg}$ per tree. The average stem carbon percentage was $62.0 \%$ from the biomass at age 20 .

\subsection{Variation of dbh, height and stem volume with the age}

All three relationships had age as the only explanatory variable and therefore both exponential and logistic curves could be fitted. However, the logistic models showed comparatively lower $\mathrm{R}^{2}$ values and in addition those were more complex than the exponential models. Therefore the exponential models shown in equations 10,11 and 12 were selected for the prediction of dbh, total height and stem volume respectively using age. $\mathrm{R}^{2}$ values for the selected models were $79.1 \%, 84.0 \%$ and $80.1 \%$ for the models 10,11 and 12 respectively. The fitted line plots of those models are given in Figures 3 to 5 .

$$
\begin{aligned}
& d b h=17.83 \times 1.028^{a g e} \\
& h=20.09 \times 1.019^{a g e} \\
& v=0.264 \times 1.066^{\text {age }}
\end{aligned}
$$

where:

$$
\begin{aligned}
d b h & =\text { diameter at breast height, } \mathrm{cm} \\
h & =\text { total tree height, } \mathrm{m} \\
v & =\text { stem volume, } \mathrm{m}^{3}
\end{aligned}
$$

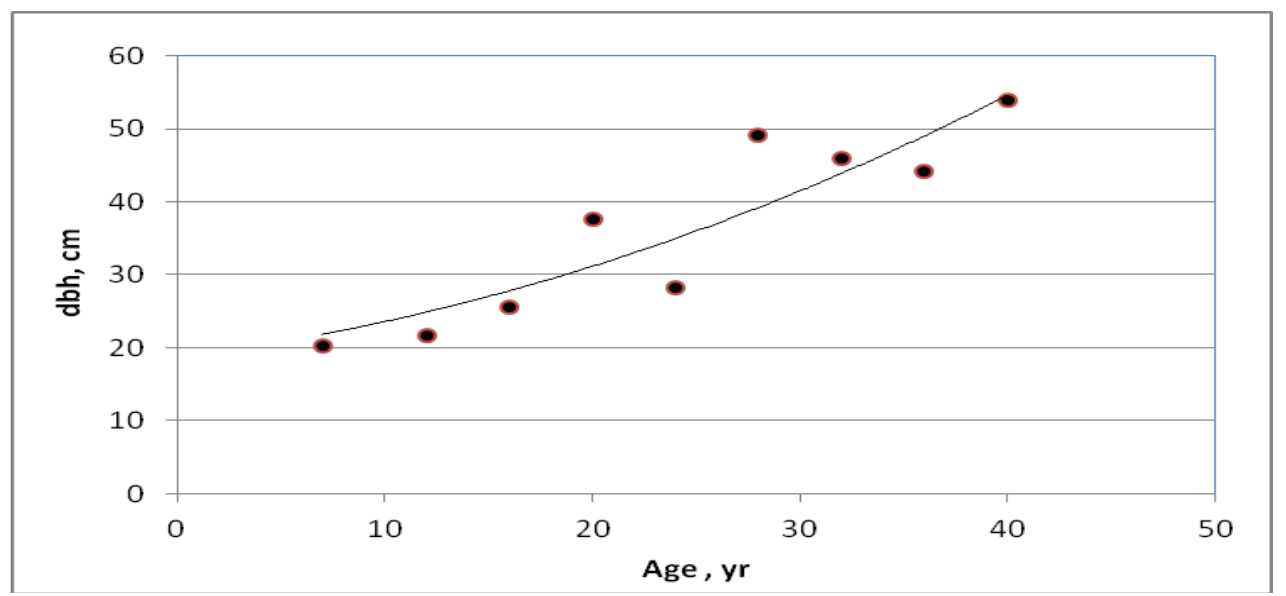

Figure 3: Average dbh values and the fitted line of equation10. 


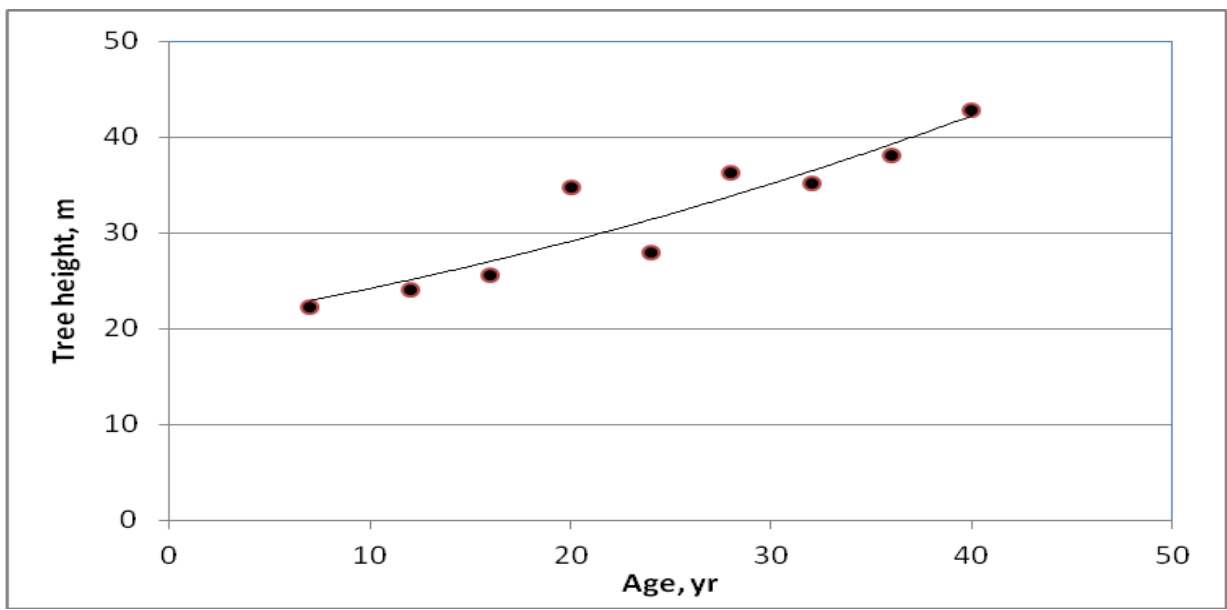

Figure 4: Average tree height values and the fitted line of equation 11.

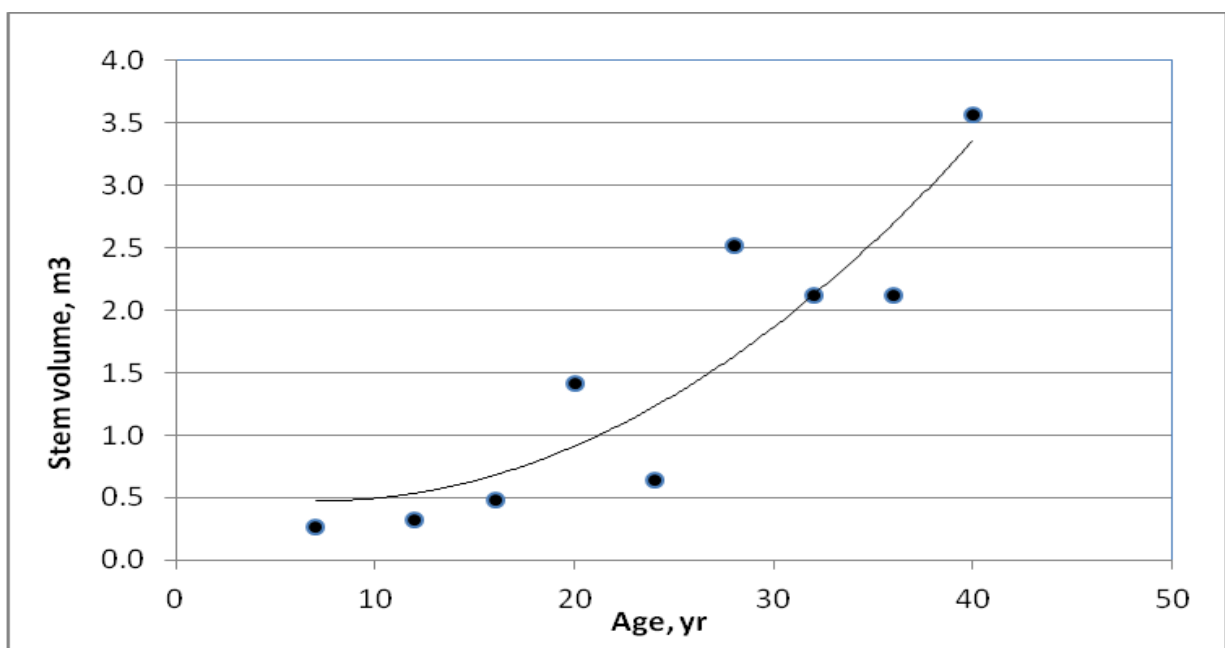

Figure 5: Average stem volume values and the fitted line of equation 12.

\subsection{Variation of stem biomass and carbon with tree age}

The exponential models resultant for the prediction of stem biomass and carbon with age are given in equation 13 and 14. The estimated $\mathrm{R}^{2}$ values were $78.7 \%$ and $82.1 \%$ respectively. Figures 6 and 7 show fitted line plots of these two models.

$$
\begin{aligned}
& B M_{\text {stem }}=108.3 \times 1.059^{a g e} \\
& C_{\text {stem }}=69.9 \times 1.059^{\text {age }}
\end{aligned}
$$

where:

$$
\begin{aligned}
& B M_{\text {stem }}=\text { stem biomass, } \mathrm{kg} \\
& C_{\text {stem }}=\text { stem carbon, } \mathrm{kg}
\end{aligned}
$$




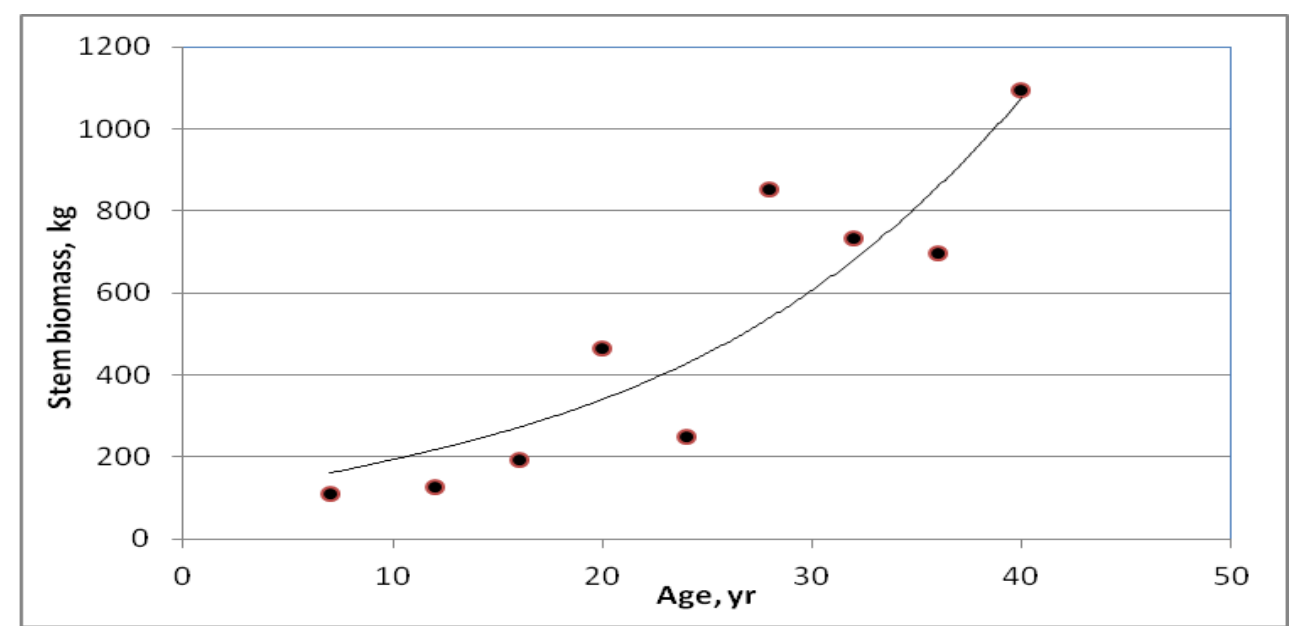

Figure 6: Average stem biomass values and the fitted line of equation 13.

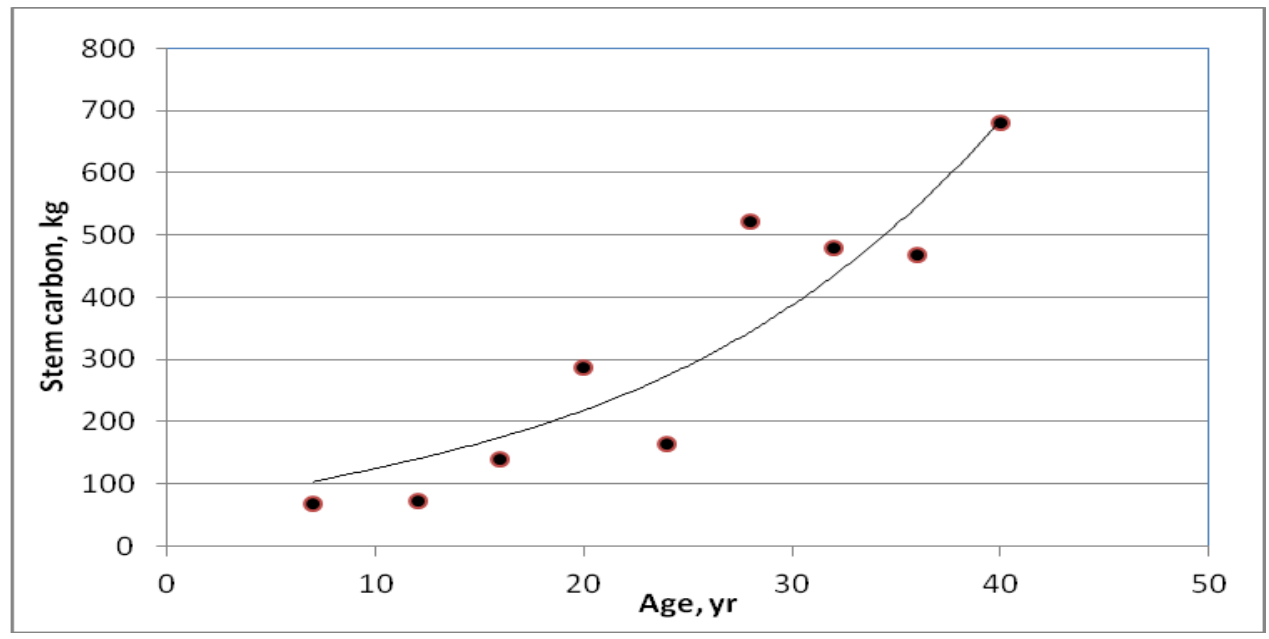

Figure 7: Average above ground stem ground carbon values and the fitted line of equation 14.

\subsection{Variation of biomass and carbon with the stem volume}

Unlike the previous models, linear modes were fitted to identify the relationships of stem biomass and carbon with stem volume. Those models are given in equations 15 to 16 .

$$
\begin{aligned}
& B M_{\text {stem }}=325.95 \times v \\
& C_{\text {stem }}=206.20 \times v
\end{aligned}
$$

Both models resulted very high $\mathrm{R}^{2}$ values proving strong relationships of biomass and carbon with the stem volume. Those values were $98.9 \%$ and $97.9 \%$. It was important to observe that the intercept of the model 15 was significant. However, in accordance with the biological reality where there is no biomass or carbon storage without stem volume. Therefore although the intercept was significant, the model was re-fitted to the data without the intercept to be compatible with the biological reality. The fitted line plots of those two models are given in Figures 8 and 9. 


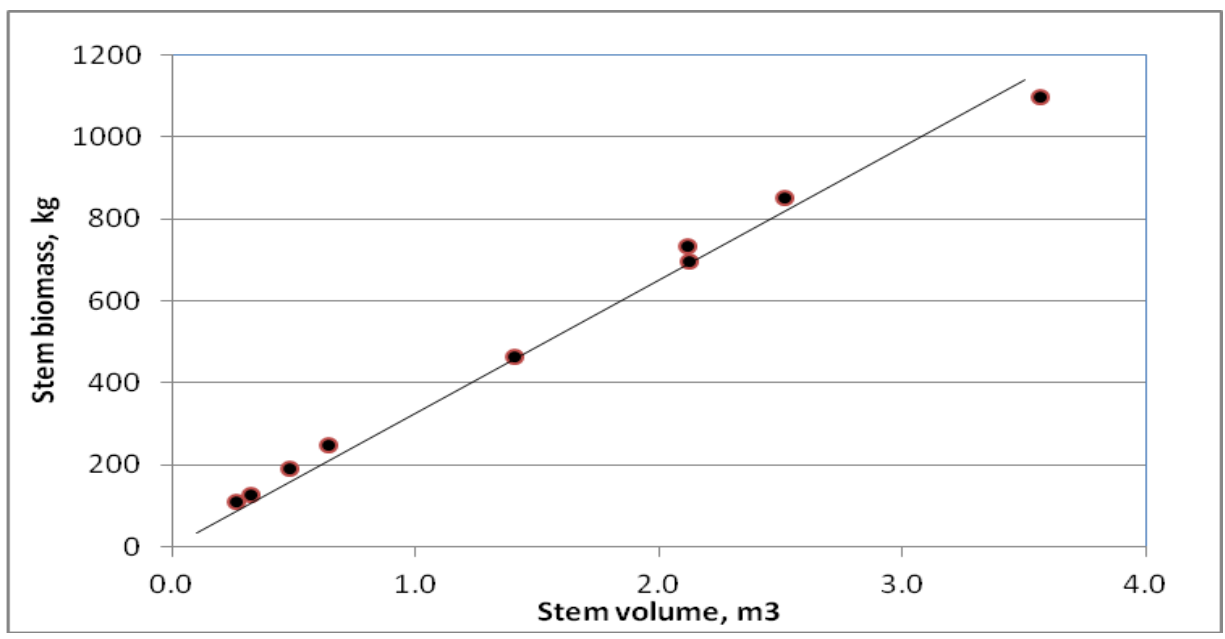

Figure 8: Average stem biomass values and the fitted line of equation 15.

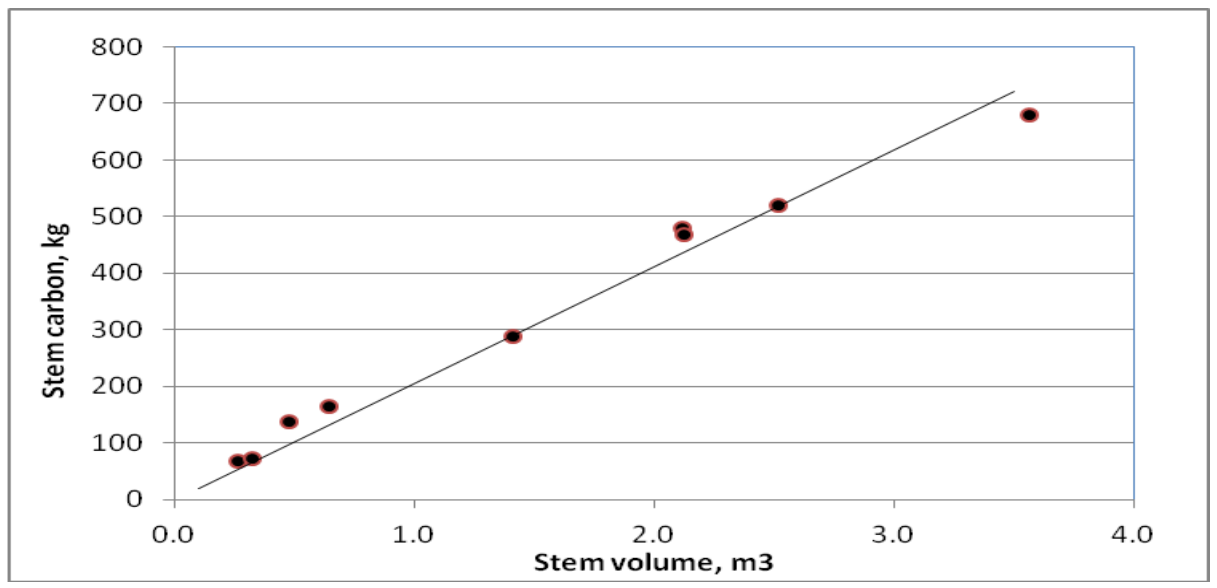

Figure 9: Average stem carbon values and the fitted line of equation 16.

\section{Discussion}

All three models built in this study using age as the explanatory variable showed positive and exponential growth pattern with the age. However, when the average values were observed in Table 1 and Figure 1, there were unusual variations of the measured values. The growth values were high at age 20 and 28 when compared with the trend of the growth in the plantations of other ages. These changes may have occurred due to the impact of the site quality on tree growth. The growth dynamics of the plant populations were determined not only by the species specific properties, but also by the biotic and abiotic factors such as neighbourhood, competition and environmental heterogeneity. This could also be one of the reasons of having unusual observations at certain ages of the E. grandis plantations used in this study.

Biomass was estimated in this study directly using the core samples taken at the breast height of trees without felling them. The density of the core samples was estimated in dry weight per green volume (Philip, 1994). Finally separate models were built in this study to predict biomass and carbon values of different above ground parts of the trees. Similar studies were conducted by Xio and Ceulemans (2004) and Wang (2006). In a different approach to the method used in this study, 
destructive sampling has also been frequently used for biomass and carbon studies of forest trees by many researchers in the past, e.g., Xio and Ceulemans (2004),Williams and Gresha (2006).

$\mathrm{R}^{2}$ values were used as the quantitative method of model evaluation in the present study. Those resultant $\mathrm{R}^{2}$ values varied from $79.1 \%$ to $98.9 \%$ for different models. Saha et al. (2004) and Wang (2006) also found similar variations in their studies on biomass and carbon of forest tree species.

Inventory data have often been used to estimate the biomass and carbon contents in tropical forests (Brown and Lugo, 1992) and in Europe (Kauppi et al., 1992). Most of such models were developed using dbh and height which are the common inventory data available in many countries (Segura and Kanninen, 2005). Considering the error that can be occurred by measuring various individual height terms, Segura and Kanninen (2005) recommended to develop models using dbh as the single explanatory variable to predict the tree carbon. However, due to the differences of the objectives, the present study built the first three models using age as the explanatory variable.

Age has become one of the essential explanatory variables for tree growth prediction in forestry (e.g.: Palahi et al., 2004, Adame et al., 2006; Salas and Garcia, 2006). However, according to Lee et al. (2004), although tree age is an important influencing variable on radial growth, it might simply be not available in practice. However, the attempts made by them to exclude the age from the explanatory variables to predict dbh growth of pine and oak were not successful and the resultant models indicated poor statistical performances.

In their modelling process, Calama et al. (2003) and Adame et al. (2006) emphasised the importance of data chosen for fitting different functions containing all possible combinations of variables. Fernandez and Norero (2006) performed forty five linear regressions in modelling the growth of branches of individual trees in each site, management and type of branch. However, exponential models were identified as the best ways of predicting the selected response variables against age in the present study. If the general form of the exponential model is considered (equation 17), the parameter $b$ became higher than one (b>1.0) for all exponential models constructed in the present study. This indicated that the selected exponential variables were growing rapidly for E. grandis even after 40 years of planting. If more data were collected beyond 40 years of age, there could be a possibility of having $b<1.0$ showing a typical sigmoid growth of biological variables.

$$
y=b_{1} \times b_{2}^{x}
$$

where:

$$
\begin{aligned}
x & =\text { explanatory variable, i.e., age in the present study } \\
y & =\text { response variable } \\
b_{1}, b_{2} & =\text { regression coefficients }
\end{aligned}
$$

In mathematical model building, it is common to transform variables into biologically accepted forms (logarithmic, square root, square and inverse) to obtain high accuracy in the predictions (e.g., Vanclay, 1994, Segura and Kanninen, 2005; Subasinghe and Gunarathne, 2007; Subasinghe and Munasinghe, 2011). Moreover, complex transformations are sometimes used in forest growth modelling. As an example, Boisvenue et al. (2004) used arcsine and cosine transformations of selected explanatory variables to model the height growth of small trees in mixed species stands in southern British Columbia in Canada. However, such transformations were not required for the linear form of 
biomass and carbon prediction models built using volume as the explanatory variable because the resultant $\mathrm{R}^{2}$ values and the fitted line plots proved that the models built in this study by using untransformed variables were strong enough.

It is commonly believed that a model can be no more accurate than the data on which it is based. However, models can amplify patterns and discard unwanted noise, they can be more accurate than the data used to build them (Burkhart, 2003). For most forested areas in tropical regions, there are limited numerical data describing the impacts of forestry practice that can be used to support the development of sustainable management practices. Anecdotal evidence may be available, but is generally of a subjective nature and site specific (Phillips et al., 2003). Continuous growth records measured from permanent sample plots are not available in Sri Lanka and therefore the measurements were taken from the temporary sample plots. However, the plantations were selected covering the entire region which is favourable for the rose gum growth in Sri Lanka along a series of age to minimise the drawback which can arise from not using permanent sample plot data.

\section{References}

Adame, A., Hynynen, J, Canellas, I., del Rio, M. 2006. Individual-tree diameter growth model for rebollo oak (Quercus pyrenaica Willd.) coppices. Forest Ecology and Management 255: 10111022 .

Bandaratillake, H.M., 2000. Administration report of the Conservator of Forests Sri Lanka for the year 2000. Forest Department, Ministry of Agriculture, Lands and Forestry, Sri Lanka.

Boisvenue, C., Temesgen, H and Marshall, P., 2004. Selecting a small tree height growth model for mixed species stands in the southern interior of British Columbia, Canada. Forest Ecology and Management, 202: 301-312.

Brown, S., Gillespie, J.R. and Lugo, A.E., 1996. Biomass of tropical forests of south and southeast Asia, Canadian Journal of Forest Research, 21: 111-117.

Brown, S., Lugo, A.E., 1992. Above ground estimates for tropical moist forests of the Brazilian Amazon. Interciencia, 17(1): 8-27.

Burkhart, H.E., 2003. Suggestions for choosing an appropriate level for modelling forest stands. In A. Amerao, D. Reed and, P. Soares (ed) Modelling forest systems, CAB International, UK.

Calama R., Cañadas N., Montero G., 2003. Inter-regional variability in site index models for even-aged stands of stone pine (Pinus pinea L.) in Spain. Annals of Forest Science, 60: 259-269.

Cairns, M.A., Brown, S., Helmer, E.H., Baumgardner, G.A., 1997. Root biomass allocation in the world's upland forests. Oecologia, 111, 1-11.

Dixon, R.K., Brown, S., Houghton, R.A, Soloman, A.M., Trexier, M.C., Wisniewski, J., 1994. Carbon pools and flux of global forest ecosystems, Science, 263:185-190.

Dye, P., 2001. Modelling growth and water use in four Pinus patula stands with the 3-PG model. South African Forestry Journal, 191: 53-63.

FAO, 1981. Eucalyptus for planting. FAO Forestry Series No. 11, Food and Agriculture Organisation of the United Nations, Rome.

Fernandez, M.P., Norero, A., 2006. Relation between length and diameter of Pinus radiata branches. Scandinavian Journal of Forest Research, 21: 124-129.

FSMP, 1995. Forestry Sector Master Plan. Forest Department, Ministry of Agriculture, Lands and Forestry, Sri Lanka. 
Gamage, Y.M.M, Subasinghe, S.M.C.U.P, Hettiarachchi, D.S., 2101, Change of seed gerwination rate with storage time of Santalum album seeds, Proceedings of $18^{\text {th }}$ International Forestry and Environmental Symposium, University of Sri Jayewardenepura, Sri Lanka.

Geary, T.F., Meskimen, G.F. and Franklin, E.C., 1983. Growing eucalypts in Florida for industrial wood production. Gen. Tech. Rep. SE-23. Asheville, NC: U.S. Department of Agriculture, Forest Service, Southeastern Forest Experiment Station.

Gower, S.T., Gholz, H.L., Nakane, K., Baldwin, V.C., 1994. Production and carbon allocation patterns of pine forests. Ecological Bulletin, 43: 115-135.

Hauhs, M., Knauft, F.J., Lange, H., 2003. Algorithmic and interactive approaches to stand growth modelling. In A. Amerao, D. Reed and, P. Soares (ed) Modelling Forest Systems, CAB International, UK.

Johnson, D.W., Todd Jr., D.E., Tolbert, V.R., 2003. Changes in ecosystem carbon and nitrogen in a loblolly pine plantation over the first 18 years. Soil Science Society American Journal, 67: 15941601.

Kauupi, P.E., Mielikainen, K, Kuusela, K., 1992. Biomass and carbon budget of European forests, 1971 to 1990. Science 256(5053): 70-74.

Ketterings, Q.M., Coe, R., van Noordwijk, M., Ambagau, Y., Palm, C.A., 2001. Reducing uncertainty in the use of allometric biomass equations for predicting above-ground tree biomass in mixed secondary forests. Forest Ecology and Management, 146: 199-209.

Kurz, W.A., Beukema, S.J., Apps, M.J., 1996. Estimation of root biomass and dynamics for the carbon budget model of the Canadian forest sector. Canadian Journal of Forest Research, 26: 19731979.

Landsberg, J.J., Linder, S., McMurtrie, R.E., 1995. Effects of global change on managed forests. A strategic plan for research on managed forest ecosystems in a globally changing environment. Global Change and Terrestrial Ecosystems. Core Project of the IGBP, Canberra, 1-17 pp.

Lee, W.K., von Gadow, K., Chung, D.J., Lee, J.L., Shin., M.Y., 2004. Dbh growth model for Pinus densiflora and Quercus variabilis mixed forests in Central Korea. Ecological Modelling, 17: 187-200.

Louw, J.H., 1999. A review of site-growth studies in South Africa. South African Forestry Journal, 185: 57-65.

Louw, J.H. and Scholes, M.C.., 2006. Site index functions using site descriptions for Pinus patula plantations in South Africa. Forest Ecology and Management, 225:94-103.

Marland, G., Marland, S., 1992, Should we store carbon in trees? Water, air and soil pollution, 64: 181-195.

Niklas, K.J., 1994. Plant allometry: The scaling of form and process. Chicago, IL: Univ. of Chicago Press.

Oliver, G.R., Pearce, S.H., Kimberly, M.O., Ford-Robertson, J.B., Robertson, K.A., Beets, P.N., Garrett, L.G., 2004. Variation in soil carbon in pine plantations and implications for monitoring soil carbon stocks in relation to land-use change and forest site management in New Zealand. Forest Ecology and Management, 203: 283-295.

Palahi M., Tome M., Pukkala T., Trasobares A., Montero G., 2004. Site index model for Pinus sylvestris in north-east Spain, Forest Ecology and Management, 187: 35-47.

Philip, M.S., 1994. Measuring trees and forests. 2nd ed. CAB International, UK.

Phillips, P.D., Brash, T.E., Yasman, I., Subagyo, P., van Gardingen, P.R., 2003. An individual-based spatially explicit tree growth model for forests in East Kalimantan (Indonesian Borneo). Ecological Modelling, 159: 1-26. 
Rodger, A.S., Samson, R.N., Sniewski, J.W., 1997. Economics of carbon sequestration in forestry, Washington, USA.

Saha, J.P., Rossa, M.S., Kopturb, S., Snyder, J.R. 2004. Estimating aboveground biomass of broadleaved woody plants in the understory of Florida Keys pine forests. Forest Ecology and Management, 203: 319-329.

Salas, C., Garcia, O., 2006. Modelling height development of mature Nothofagus oblique. Forest Ecology and Management, 229: 1-6.

Samarasekara, S.C., 2013. Variation of quantity and quality of Santalum album L. oil with geographical, topographical and host species in selected districts, BSc Dissertation, Department of Forestry and Environmental Science, University of Sri Jayewardenepura, Sri Lanka.

Sedjo, R., 1990. The global carbon cycle. Journal of forestry, 88: 33-34.

Segura, M., Kanninen, M., 2005. Allometric models for tree volume and total above ground biomass in a tropical humid forest in Costa Rica. Biotropica, 37(1): 2-8.

St. Clair, J.B., 1993. Family differences in equations for predicting biomass and leaf area in Douglas fir (Pseudotsuga menziesii var. menziesii). Forest Science, 39:743-755.

Subasinghe, S.M.C.U.P., 2001. Construction of an individual tree volume prediction model for Eucalyptus grandis Hill ex Maiden in Sri Lanka, Research Report, University of Sri Jayewardenepura, Sri Lanka.

Subasinghe, S.M.C.U.P. and Gunarathne, W.P.K. 2007. Construction of a precise growth model to predict the individual tree stem volume for mature Tectona grandis L.f. (Teak). Sri Lanka Forester, 30-31: 1-13.

Subasinghe, S.M.C.U.P. and Munasinghe, G.B., 2011. Estimation of above ground tree biomass and carbon of Pinus caribaea (Morelet). Journal of Tropical Forestry and Environment. 1(1): 56-70.

Subasinghe, S.M.C.U.P. and Haripriya, A.M.R., 2014. Prediction of stem biomass of Pinus caribaea growing in the low country wet zone of Sri Lanka. Journal of Tropical Forestry and Environment, 4(1): 40-49.

Vanclay, J.K., 1994. Modelling forest growth and yield: Applications to mixed tropical forests. CAB International, UK.

Wang, C., 2006. Biomass allometric equations for 10 co-occurring tree species in Chinese temperate forests, Forest Ecology and Management, 222: 9-16.

Williams, T., Gresham, C.A. 2006. Biomass accumulation in rapidly growing loblolly pine and sweet gum. Biomass and Bioenergy 30: 370-377.

Xiao, C.W., Ceulemans, R. 2004. Allometric relationships for below- and aboveground biomass of young Scots pines. Forest Ecology and Management, 203: 177-186. 